\title{
Pengaruh Stress Kerja Terhadap Perilaku Produktif Ditinjau dari Pemberian Kompensasi yang Standar
}

\author{
Nazilatur Rochmawati1) \\ Fakultas Psikologi Universitas Yudharta Pasuruan \\ E-mail: fpsi@gmail.com \\ M. Wardianto $^{2)}$ \\ Fakultas Psikologi Universitas Yudharta Pasuruan \\ E-mail: maswardi.wm@gmail.com
}

\begin{abstract}
Employee work productivity is the main thing in maintaining and even improving the quality and strength of the company. This is a challenge that is not easy for employees. One aspect that is often discussed with this variable is the level at which employees work. The purpose of this study was to determine the relationship between work stress and productive relationships at PT. Uniplastindo Interbuana, Pasuruan. The results showed that the hypothesis stating there was a relationship between work stress and productifity was rejected at the 5\% significance level, where the rxy of -0.203 $<\mathrm{r}$ table $5 \%$ of 0.279 . Thus the level of work stress of employees is not a significant factor for predicting the level of productivity of competition.
\end{abstract}

Keywords: productive behavior, work stress, Compensation.

Abstrak. Produktivitas kerja karyawan merupakan hal utama dalam mempertahankan bahkan meningkatkan kualitas maupun kuantitas suatu perusahaan. Namun tantangan untuk memelihara produktivitas karyawan ini juga tidak mudah. Salah satu aspek yang sering dikaitkan dengan variabel ini adalah tingkat disstres karyawan saat bekerja. Tujuan penelitian ini adalah untuk mengetahui hubungan antara stress kerja dengan perilaku produktif di PT. Uniplastindo Interbuana, Pasuruan. Hasil penelitian menunjukkan bahwa hipotesis yang menyatakan ada hubungan antara stress kerja dengan perilaku produktif ditolak pada taraf signifikansi $5 \%$, dimana rxy sebesar $0,203<\mathrm{r}$ tabel $5 \%$ sebesar 0,279. Dengan demikian tinggi rendahnya stress kerja seorang karyawan tidak menjadi faktor yang signifikan untuk meramalkan tingkat produktivitas kerjanya.

Kata Kunci: perilaku produktif, stress kerja, Kompensasi. 
Perkembangan zaman yang semakin pesat membuat dunia perindustrian mau tidak mau harus berkompetisi demi mendapatkan profit yang lebih dengan meningkatkan mutu sumber daya manusia yang mereka miliki, karena salah satu faktor kejayaan suatu perusahaan juga terletak pada sumber daya manusia yang konkret. Dengan demikian, diperlukan manajemen secara seksama sehingga dapat meningkatkan kualitas produknya, yang salah satunya melalui pengelolaan sumberdaya manusia dimana pengelolaan sumber daya manusia yang efektif yaitu dengan mengarahkan karyawan ke arah yang produktif.

Adanya perilaku produktif dalam suatu perusahaan harus dimulai dari awal, yakni dengan menumbuhkan budaya produktif dalam perusahaan yang melalui tiga tahap diantaranya, adanya kesadaran dari masing-masing pekerja akan pentingnya masalah produktivitas, kemudian adanya peningkatan, yakni guna meningkatkan produktivitas maka perlu dikuasai keterampilan pengukuran dan analisa produktivitas, dan yang terakhir yakni memelihara yang sudah diperoleh. Apabila hal-hal tersebut dilaksanakan dengan baik maka akan menimbulkan budaya produktif, dimana budaya produktif ini akan berdampak terhadap proses pembentukan pekerja yang produktif juga (Sinungan, 2003)

Dalam upaya menumbuhkan budaya produktif dan perilaku produktif guna meningkatkan kualitas Sumber Daya Manusia (SDM) dan kuantitas hasil perusahaan tidak jarang mereka yang sukses dan berhasil dengan mudah karena didalam ruang lingkup organisasi maupun industri banyak sekali kita temui konflik-konflik yang dapat menghambat aktivitas maupun perilaku produktif kerja seseorang pada perusahaan yang kecil hingga yang besar, baik itu masalah interpersonal, intrapersonal maupun social. Sebagai contoh kecil yang sering kita keetahui dalam kehidupan sehari-hari di lingkungan kerja adalah masalah stress, dimana stress dalam pekerjaan ini bisa disebabkan oleh berbagai hal, misalnya kecilnya gaji 
yang diterima (kompensasi), frustasi, kecemasan, tanggung jawab, beban kerja, lingkungan kerja, iklim organisasi dsb, Sehingga hal itu menyebabkan ketidakseimbangan antara kondisi fisik, psikis, maupun sikap pada seseorang yang akhirnya dapat memicu timbulnya berbagai masalah didalam pekerjaan maupun di luar pekerjaan, terutama akan berimbas pada perilaku produktif kerja karyawan.

Stress merupakan suatu hal yang abstraksi. Orang tidak dapat melihat apa yang menjadi pembangkit stress akan tetapi yang bisa dilihat adalah akibat dari pembangkit stressnya. Selain hal di atas perlu dikemukakan juga bahwasannya didalam suatu organisasi industri masalah stress yang timbul juga dapat dipicu oleh besar kecilnya kompensasi yang diterima karyawan sehingga hal tersebut juga berdampak pada perilaku mereka yang menjadi tidak produktif, dan juga menghambat produktivitas kerjanya. Kompensasi yang tidak sesuai dengan kebutuhan karyawan dapat menjadi pemicu timbulnya ketidakpuasan yang dialami oleh seseorang karena ketidaksesuaiannya dengan kebutuhan hidup secara ekonomi maupun sosial baik di lingkungan rumah tangga, didalam pekerjaan maupun perusahaannya itu sendiri, sehingga seseorang itu juga mengalami stress kerja. Dimana Stress kerja merupakan suatu perasaan yang menekan atau rasa tertekan yang dialami karyawan dalam menghadapi pekerjaannya (Mangkunegara, 1993). Dari uraian itu dapat diketahui bahwa tekanan-tekanan yang dirasakan seorang karyawan tidak lain juga merupakan akibat dari kompensasi yang tidak sesuai sehingga menyebabkan stress kerja dan perilaku produktifnya pada saat bekerja menurun.

Sinungan

mengelompokkan pengertian produktivitas menjadi tiga, yaitu sebagai berikut:

1. Rumusan tradisional bagi keseluruhan produktivitas tidak lain ialah ratio daripada apa yang dihasilkan (output) terhadap keseluruhan peralatan produksi yang dipergunakan (input). 
2. Produktivitas pada dasarnya adalah suatu sikap mental yang selalu mempunyai pandangan bahwa mutu kehidupan hari ini lebih baik dari pada kemarin, dan hari esok lebih baik dari hari ini.

3. Produktivitas merupakan interaksi terpadu secara serasi dari tiga faktor esensial, yakni: investasi termasuk penggunaan pengetahuan dan teknologi serta riset, manajemen, dan tenaga kerja.

Perilaku produktif yang muncul pada seseorang hanya ada pada orangorang yang memiliki pribadi yang produktif, dimana pribadi yang produktif itu akan menggambarkan persepsi, potensi, kreativitas seseorang yang ingin selalu memberikan sesuatu yang bermanfaat tidak hanya untuk dirinya tetapi juga untuk lingkungannya. Pada saat yang bersamaan orang-orang seperti ini akan selalu bertanggung jawab dengan apa yang ada ditangannya dan selalu responsif dengan keadan disekitarnya dalam hal ini mereka dapat dijadikan sebagai pemimpin yang baik dan merupakan aset utama dalam sebuah organisasi maupun perusahaan, dikarenakan dengan adanya keberadaan mereka maka produktivitas perusahaan dapat meningkat.

Dengan adanya hal di atas maka dijelaskan disini bahwa pribadi yang produktif adalah pribadi yang yakin akan kemampuan dirinya, yang dalam istilah psikologi biasanya disebut sebagai orang yang memiliki rasa percaya diri, harga diri, dan konsep diri yang tinggi pula (Sedarmayanti, 2001). Dan perilaku produktif hanya ada pada mereka orang-orang yang produktif pula.

Ada beberapa faktor yang dapat mempengaruhi perilaku produktif karyawan yaitu, antara lain:

1. Semangat Kerja: Semangat kerja adalah sikap dari individu ataupun sekelompok orang terhadap kesukarelaannya untuk bekerjasama agar dapat mencurahkan kemampuannya secara menyeluruh.

2. Disiplin Kerja: Disiplin kerja juga diartikan sebagai sikap ketaatan seseorang terhadap suatu aturan / 
ketentuan yang berlaku dalam organisasi yaitu menggabungkan diri dalam organisasi itu atas dasar adanya kesadaran dan keinsyafan bukan karena adanya unsur paksaan.

3. Stress: Sifat internal yang merupakan konsekuensi dari tindakan atau situasi eksternal baik fisik maupun psikis yang mencakup rasa takut, rasa bersalah, cemas, marah, sedih, putus asa dan bosan yang dapat berasal dari individu yang berada di sekitar lingkungan kerja kita baik dalam maupun dari luar organisasi.

4. Tingkat pendidikan: Pada umumnya orang mempunyai pendidikan lebih tinggi cenderung akan mempunyai wawasan yang luas terutama penghayatan akan arti pentingnya produktivitas, pengertian pendidikan disini berasal dari pendidikan formal atau non formal. Tingginya kesadaran akan arti pentingnya produktivitas dapat mendorong tenaga kerja yang bersangkutan melakukan tindakan yang produktif.

5. Keterampilan: Pada aspek tertentu kalau tenaga kerja makin terampil maka akan lebih terampil kalau mempunyai kecakapan (ability) dan pengalaman (experience) yang cukup.

6. Manajemen: Pengertian manajemen disini dapat dikaitkan dengan sistem yang diterapkan oleh pimpinan yang mengelola ataupun memimpin serta mengendalikan karyawan bawahannya. Apabila manajemennya tepat maka akan menimbulkan semangat yang lebih tinggi sehingga dapat mendorong tenaga kerja untuk melakukan tindakan yang produktif.

7. Tingkat penghasilan: Apabila tingkat penghasilan memadai dapat menimbulkan perilaku untuk konsentrasi kerja dan kemampuan yang dimiliki dapat dimanfaatkan untuk meningkatkan produktivitas.

8. Gizi dan kesehatan: Apabila tenaga kerja terpenuhi kebutuhan 
gizi dan berbadan sehat maka akan lebih kuat bekerja dan mempunyai semangat yang tinggi untuk dapat meningkatkan produktivitas.

9. Jaminan sosial: Jaminan sosial yang diberikan suatu perusahaan kepada karyawannya dimaksudkan untuk meningkatkan pengabdian dan semangat kerja. Apabila jaminan sosialnya mencukupi maka akan menimbulkan kesenangan kerja, sehingga mendorong perilaku produktif dalam pemanfaatan kemampuan yang dimiliki untuk meningkatkan produktivitas.

10. Lingkungan dan Iklim: Lingkungan dan iklim kerja yang baik akan mendorong tenaga kerja untuk betah bekerja dan meningkatkan rasa tanggungjawab untuk melakukan pekerjaan dengan baik kearah peningkatan produktivitas.

11. Sarana produksi: Mutu sarana produksi berpengaruh sekali pada peningkatan produktivitas. Apabila sarana produksi yang digunakan oleh tenaga kerja yang terampil akan mendorong peningkatan efisiensi ataupun produktivitas.

12. Teknologi: Apabila teknologi yang dipakai adalah tepat dan sudah lebih maju tingkatannya maka memungkinkan untuk tepat waktu dalam penyelesaian proses produksi; jumlah produksi yang dihasilkan lebih banyak dan bermutu; dan memperkecil terjadinya pemborosan bahan sisa.

Pada dasarnya perilaku produktif pada sebuah perusahaan merupakan akumulasi dari perilaku produktif individu-individu (karyawankaryawan) sehingga untuk memperbaiki perilaku produktif perusahaan diperlukan komitmen perbaikan yang seimbang antara aspek manusia (motivasi) dan aspek teknik (teknologi). Peningkatan perilaku produktif perusahaan harus dimulai dari tingkat individu.

Secara klinis stress adalah suatu keadaan dimana beban yang dirasakan seseorang tidak sepadan dengan kemampuan untuk mengatasinya (Slamet dan Markam, 2003). Stress 
menunjukkan adanya tekanan atau tuntutan yang dialami oleh individu atau organisme agar ia beradaptasi atau menyesuaikan diri, dapat terjadi karena adanya beberapa faktor, dan faktor-faktor yang menyebabkan stress atau menjadi sumber stress dinamakan dengan stressor (Nevid et al, 2003).

Stress yang terjadi pada seseorang dapat menjadi suatu hambatan dalam beraktivitas terlebih ketika orang tersebut berkecimpung dalam dunia perindustrian. Jika seseorang mengalami stress pada saat dia bekerja maka hal ini akan menimbulkan suatu keadaan yang dinamakan dengan stress kerja.

Seperti yang diungkapkan oleh Mohyi (2012), stress kerja adalah perasaan tertekan atau suatu ketegangan mental seseorang terkait dengan pekerjaannya yang terjadi karena pengaruh situasi atau peristiwa diri dan lingkungan, baik lingkungan pekerjaan maupun diluar pekerjaan. Sedangkan Beehr dan Newman (Wijono, 2010) mendefinisikan stress kerja sebagai suatu keadaan yang timbul dalam interaksi antara manusia dengan pekerjaan. Oleh karena itu apabila seorang mengalami stress dalam pekerjaannya maka orang tersebut produktivitas kerjanya akan menurun karena keadaan fisik dan psikisnya sedang dalam kondisi yang tidak stabil.

Mohyi (2012) dan Hurrel dkk dalam Munandar mengemukakan beberapa faktor yang dapat menyebabkan stres.

Menurut Mohyi (2012) beberapa faktor stres antara lain faktor lingkungan, organisasional, dan individual (keluarga, kepribadian, ekonomi). Sedangkan faktor stres menurut Hurrel dkk (Munandar, 2008) antara lain:

1. Faktor intrinsik dalam pekerjaan, yakni adanya tuntutan fisik dan tuntutan tugas. Dimana tuntutan fisik ini merupakan kondisi fisik kerja yang mempunyai pengaruh terhadap kondisi faal dan psikologis seorang tenaga kerja, dan kondisi fisik ini dapat merupakan pembangkit stress. Misalnya, kebisingan, vibrasi (getaran), hygiene (kebersihan). Sedangkan tuntutan tugas merupakan beban tanggung jawab 
yang diberikan kepada karyawan. Misalnya: shift kerja, beban kerja yang terlalu banyak atau sedikit.

2. Peran individu dalam organisasi, meliputi konflik peran yaitu ketidakcakapan seseorang untuk memenuhi tuntutan-tuntutan dan berbagai harapan pada dirinya, dan ketaksaaan peran yaitu jika seorang tenaga kerja tidak memiliki cukup informasi untuk dapat melaksanakan tugasnya, atau tidak mengerti atau merealisasi harapa-harapan yang berkaitan dengan peran tertentu.

3. Pengembangan karir meliputi, job Insecurity, over and under promotion. Job insecurity yaitu ketakutan seseorang akan kehilangan pekerjaan, ancaman bahwa pekerjaannya dianggap tidak diperlukan lagi. Over and under promotion yaitu besar kecilnya peluang untuk meningkatkan karir dalam pekerjaan.

4. Hubungan dalam pekerjaan. Hubungan yang baik antaranggota dari satu kelompok kerja dianggap sebagai faktor utama dalam kesehatan individu dan organisasi (Argyris, 1964; Cooper, 1973). Stress yang timbul juga dikarenakan tenaga kerja harus bekerja sama dengan tenaga kerja lain yang berkepribadian "kasar", orang yang tidak memperhatikan perasaan dan kepekaan dalam interaksi sosial, dan orang yang "dingin".

5. Struktur dan iklim organisasi. Faktor stress yang ditemukenali dalam kategori ini terpusat pada sejauh mana tenaga kerja dapat terlibat atau berperan serta pada support sosial.

6. Tuntutan dari luar pekerjaan. Kategori pembangkit stress potensial ini mencakup segala unsure kehidupan seseorang yang dapat berinteraksi dengan peristiwa-peristiwa kehidupan dan kerja dalam satu organisasi, dan dengan demikian member tekanan pada individu.

7. Ciri-ciri individu. Dalam hal ini Reaksi-reaksi psikologis, fisiologis dan atau dalam bentuk perilaku terhadap stress adalah hasil dari interaksi situasi dengan individunya, mencakup ciri-ciri 


kepribadian yang khusus dan pola
perilaku yang didasarkan pada
sikap, kebutuhan, nilai-nilai,
$\begin{aligned} & \text { pengalaman lalu, keadaan } \\ & \text { kehidupan serta juga }\end{aligned}$
$\begin{array}{ll}\text { (antara lain inteligensi, } \\ \text { pendidikan, } \\ \text { pembelajaran). }\end{array}$

Menurut Sedarmayanti (2007) kompensasi adalah segala sesuatu yang diterima oleh karyawan sebagai balas jasa kerja mereka. Disi lain, menurut McNamara (2008 dalam Marwansyah, 2012) kompensasi adalah pembayaran kepada seorang karyawan sebagai balasan atas kontribusinya terhadap organisasi.

Selanjutnya Mondy (2005, dalam Marwansyah, 2012) kompensasi adalah keseluruhan imbalan yang diberikan kepada para karyawan sebagai balasan atas jasa atau kontribusi mereka terhadap organisasi. Pernyataan tersebut sesuai dengan apa yang dikemukakan oleh Marwansyah (2012), bahwa kompensasi adalah penghargaan atau imbalan langsung maupun tidak langsung, financial maupun non financial yang adil dan layak kepada karyawan, sebagai balasan atas kontribusi terhadap pencapaian tujuan organisasi.

Sebuah organisasi atau perusahaan dapat dianalogikan sebagai tubuh manusia. Jika salah satu dari anggota tubuh itu terganggu, maka akan menghambat keseluruhan gerak, menyebabkan seluruh tubuh merasa sakit dan menyebabkan individunya tidak dapat berfungsi secara normal. Demikian pula jika banyak di antara karyawan di dalam organisasi mengalami stress kerja, maka produktivitas dan kesehatan organisasi itu akan terganggu. Jika stress yang dialami oleh organisasi atau perusahaan tidak kunjung selesai, maka sangat berpotensi mengundang penyakit yang lebih serius. Bukan hanya individu yang bisa mengalami penyakit, organisasi pun dapat memiliki apa yang dinamakan penyakit organisasi (Rini, 2002). Stress kerja sangat memiliki pengaruh yang cukup besar terhadap perilaku produktif tenaga kerja, karena stress merupakan suatu kondisi ketegangan yang mempengaruhi emosi, proses berpikir dan kondisi seseorang. 
Seperti yang dikatakan oleh Mohyi (2012) stress kerja yang rendah akan berpengaruh terhadap rendahnya kinerja atau produktivitas karena karyawan merasa bosan dan motivasi menurun, stress kerja yang sedang berpengaruh terhadap meningkatnya produktivitas kerja karena karyawan merasa adanya tantangan dalam bekerja serta ada motivasi untuk menyelesaikan tugas dan tanggung jawab dengan baik, dan stress kerja yang tinggi juga berpengaruh terhadap rendahnya produktivitas kerja karena karyawan akan merasa tersiksa batin, susah tidur, keraguan dalam bekerja, kesalahan meningkat yang pada akhirnya mengakibatkan produktivitas kerja menurun.

Lawton (Winarsunu, 2011) juga berpendapat bahwa pemahaman tentang stress dengan hubungan perilaku berbahaya yang menyebabakan kecelakaan kerja didasarkan pada pendapat Reason (1990) yang menyatakan bahwa stress dapat mempengaruhi keadaan kognisi seseorang dalam bentuk munculnya keadaan lupa sehingga menimbulkan kesalahan-kesalahan pada waktu melakukan pekerjaan.

Stress kerja dan perilaku produktif adalah hal yang saling berkaitan. Adakalanya seseorang yang mengalami stress berdampak positif sehingga dapat meningkatkan perilaku produktif nya karena mereka merasa ada dorongan yang kuat dalam dirinya dan semakin tertantang untuk menyelesaikan permaslahan yang ada dalam pekerjaannya, namun sangat banyak juga stress yang berdampak negatif sehingga menurunkan perilaku produktif yang dapat mengganggu aktivitasnya dalam bekerja dan dapat merugikan perusahaan. Selain itu pemberian kompensasi yang tepat dan adil sesuai dengan prinsip manajemen dan kebutuhan hidup serta sesuai dengan peraturan perundangundangan, akan membuat perasaan tenaga kerja lebih tentram dan puas dalam bekerja sehingga memicu motivasi dan semangat yang lebih tinggi untuk menghasilkan perilaku produktif kerja yang tinggi pula, dan mengurangi resiko stress kerja yang dapat terjadi kapan saja, serta dapat 
meningkatkan hasil produksi perusahaan itu sendiri.

\section{Metode}

Penelitian ini menggunakan metode penelitian korelasional karena penelitian yang dilakukan ingin mengetahui sejauh mana variabel pada suatu faktor berkaitan dengan variabel pada satu atau lebih faktor lain berdasarkan pada koefisien korelasi dengan menggunakan metode skala dalam pengumpulan datanya.

Variabel tergantung dalam penelitian ini adalah perilaku produktif, dan variabel bebasnya adalah stress kerja, sedangkan kompensai merupakan variabel kontrol dalam penelitian ini.

Teknik pengambilan sampel yang digunakan adalah simple random sampling, yaitu teknik pengambilan sampel secara acak sederhana, dimana nama-nama subyek diambil dari data perusahaan yang telah mengikuti psikotes, kemudian sampel diambil dengan cara acak berdasarkan urutan angka prima. Sampel yang diambil dalam penelitian ini berjumlah 50 orang yang bekerja dibagian produksi.
Untuk menguji data validitas skala perilaku produktif menggunakan perhitungan koefisien korelasi dengan komputasi formula korelasi productmoment dari Pearson. Sedangkan untuk menguji data reliabilitas skala perilaku produktif menggunakan perhitungan melalui teknik formula koefisian alpha $(\alpha)$. Sedangkan untuk menguji data validitas skala stress kerja menggunakan perhitungan koefisien korelasi dengan komputasi formula korelasi product-moment dari Pearson. Sedangkan untuk menguji data reliabilitas skala stress kerja menggunakan perhitungan melalui teknik Formula Rulon. Selanjutnya analisis regresi satu prediktor digunakan untuk melihat apakah ada hubungan antara variabel bebas dan variabel tergantung.

\section{Hasil}

Dari perhitungan statistik dengan menggunakan teknik analisis regresi, satu-prediktor maka dapat diketahui bahwa hipotesis dalam penelitian ini yang berbunyi "ada hubungan antara Stress Kerja dengan Perilaku Produktif", ditolak. Hal ini 
sesuai dengan hasil perhitungan statistik yang diketahui sebesar -0,203 yang lebih kecil dari $\mathrm{F}$ tab 5\% sehingga hasil yang diperoleh tidak signifikan.

Dari hasil korelasi diperoleh rxy sebesar -0,203 pada taraf signifikansi $\mathrm{F}$ tab 5\% dengan demikian tidak ada korelasi yang signifikan antara stress kerja dengan perilaku produkitf. Dengan demikian stress kerja tidak dapat digunakan untuk meramalkan perilaku produktif seseorang, hal ini dapat dilihat dari koefisien determinan $\mathrm{R}^{2}$ sebesar $4,102 \%$ yang menunjukkan bahwa sumbangan stress kerja terhadap perilaku produktif sangat kecil.

Untuk menguji signifikansi regresi dilakukan analisa regresi, yang diperoleh harga $F_{\text {reg }}$ sebesar -0,1236 dengan $\mathrm{F}$ tabel $5 \%=3,84$ sehingga dinyatakan tidak signifikan, artinya tidak ada korelasi antara pengaruh stress kerja terhadap perilaku produktif. Dengan demikian hipotesis yang menyatakan "ada pengaruh antara stress kerja dengan perilaku produktif" ditolak".

Tabel 1.

Ringkasan Analisis Varians Regresi

\begin{tabular}{lccrcc}
\hline Sumber Variasi & db & JK & RK/MK & F reg & $\begin{array}{c}\text { F Tab 5\% } \\
\text { F Tab 1 \% }\end{array}$ \\
\hline Regresi (Reg) & 1 & $-3,551$ & $-3,551$ & $-0,1236^{*}$ & 3,84 \\
\hline Residu (Res) & 48 & 1379,07 & 28,73065 & & 6,63 \\
\hline Total (T) & 49 & 1375,52 & - & & - \\
\hline$\left.{ }^{*}\right)$ Tidak signifikan & & & & &
\end{tabular}

Diskusi

Perilaku produktif tidak hanya dipengaruhi oleh faktor stress saja, tetapi ada faktor lain yang mempengaruhinya seperti semangat kerja, motivasi kerja, lingkungan dan iklim kerja juga dapat mempengaruhi perilaku produktif seseorang. Stress kerja yang terjadi tidak dapat dipastikan secara mutlak berpengaruh terhadap penurunan perilaku produktif karena stress kerja yang terjadi pada seseorang dapat merubah keadaan diri seseorang menjadi lebih aktif ataupun lebih pasif saat bekerja. 
Selain itu faktor lain yang juga dapat mempengaruhi perilaku produktif adalah Adversity Quotient. Dimana Adversity Quotient (AQ) adalah suatu kerangka konseptual yang mampu meramalkan seberapa jauh seseorang mampu mengatasi kesulitan-kesulitan dalam hidup. Menurut Stoltz (2000), setiap individu mempunyai tingkat $\mathrm{AQ}$ yang berbeda dan dapat dikategorikan menjadi beberapa tipe yaitu, Climbers yakni tipe yang memiiki AQ paling tinggi. Dalam dunia kerja, Climbers menyambut baik tantangan-tantangan dan hidup dengan pemahaman bahwa ada hal-hal yang mendesak dan harus segera dibereskan, mereka dapat memotivasi dirinya sendiri dan memiliki semangat yg tinggi serta berjuang untuk mendapatkan yang terbaik dalam hidup. Dengan kata lain Climbers dapat mengubah stress menjadi Eustress untuk meningkatkan perilaku produktifnya. Kedua, adalah tipe Campers yakni tipe yang melepaskan kesempatan untuk maju, yang sebenarnya dapat dicapai jika energi dan sumber dayanya diarahkan dengan tepat. Dalam dunia kerja tipe ini Campers masih menunjukkan sejumlah inisiatif, sedikit semangat dan beberapa usaha. Mereka menggunakan seluruh kemampuannya, tetapi yang dikerjakannya cukup membuatnya tetap bisa dipekerjakan oleh perusahaan. Tipe ini juga masih memiliki visi untuk bekerja semaksimal mungkin. Meskipun mereka selalu mengambil jalan yang aman dan penuh perhitungan serta memiliki ancaman resiko yang kecil. Dengan kata lain tipe ini memiliki perilaku produktif dalam tingkat yang sedang-sedang saja yang sewaktuwaktu bisa ditingkatkan atau hanya sampai pada titik puncak tertentu. Tipe yang terakhir yakni Qiutters, yaitu Kelompok ini termasuk orangorang yang menghindari kewajiban, memilih untuk mundur, berhenti. Dalam bekerja mereka memperlihatkan sedikit ambisi, semangat minim, dan mutu dibawah standar. Quitters tidak banyak memberikan sumbangan yang berarti dalam pekerjaan, sehingga merupakan beban bagi perusahaan, tidak memiliki visi yang bagus keyakinan akan masa 
depan Akibatnya Quitters lebih sedikit dalam menghasilkan kinerja, kontribusi dalam produktivitas sangat kecil. Oleh karena itu dapat dikatakan bahwa orang dengan tipe ini memiliki perilaku produktif yang sangat rendah dibanding Campers terlebih lagi dengan Climbers.

Menurut Suhariadi

dalam jurnal "Deskriptif Adversity Quotient dan perilaku produktif dari pemogok kerja" Dimensi perilaku produktif menjelaskan bahwa ada faktor-faktor yang diperkirakan berdampak pada munculnya perilaku produktif yang terindikasikan efeknya pada peningkatan produktivitas kerja. Drucker menyatakan bahwa peningkatan produktivitas individual terletak pada komitmen manajemen. Sedangkan Caudron menyatakan bahwa muncul tidaknya perilaku produktif pada dasarnya lebih dikarenakan faktor budaya.

Selain itu suasana kerja bisa mempengaruhi perilaku seseorang saat dia bekerja dan nantinya akan berpengaruh terhadap produktivitasnya. Banyak situasi atau suasana kerja yang berpengaruh terhadap produktivitas kerja seseorang, seperti yang dikemukakan oleh Carrilo \& Kopelman (1991 dalam Suhariadi, 2004), suasana organisasi yang berpengaruh terhadap tingkat produktivitas kerja adalah struktur organisasi itu sendiri, sedangkan menurut Frisch \& Dickinson (1990 dalam Suhariadi, 2004) adalah berupa gaji, bonus dan insentif, dan menurut Witt \& Beorkrem (1989 dalam Suhariadi, 2004) adalah berupa iklim kerja organisasi. Jadi secara langsung maupun tidak langsung situasi atau suasana kerja akan mempengaruhi karyawan dalam bekerja.

$$
\text { Menurut Moekijat }
$$
mengatakan bahwa "iklim kerja adalah hal-hal yang menguntungkan dan tidak menguntung-kan bagi orangorang dalam organiasi". Jika kondisi dalam perusahaan menguntungkan bagi karyawan maka akan membuat tingkat stres menjadi stabil yang akan berpengaruh terhadap perilaku produktif dan sebaliknya jika kondisi perusahaan tidak menguntungkan maka perilaku produktif karyawan juga tidak akan lahir. 


\section{Kesimpulan}

Dari hasil penelitian yang telah dilakukan dapat ditarik kesimpulan, yaitu bahwa tidak ada hubungan yang signifikan antara stress kerja dengan perilaku produktif di PT. Uniplastindo Interbuana. Hipotesa yang menyatakan bahwa ada hubungan stress kerja dengan perilaku produktif ditolak. Hal ini dikarenakan banyaknya faktor yang dapat mempengaruhi perilaku produktif karyawan selain stress kerja yang bisa jadi memiliki potensial aksi lebih tinggi dibanding dengan stress kerja pada karyawan, misalnya seperti iklim kerja, semangat kerja, sistem managemen dan lain-lain.

\section{Referensi}

Mangkunegara, A. P. (1993). Psikologi Perusahaan. Bandung: Trigenda Karya.

Marwansyah. (2012). Manajemen Sumber Daya Manusia. Bandung: Alfabeta.

Moekijat. (1995). Manajamen Personalia dan Sumber Daya Manusia. Bandung: Mandar Maju.

Mohyi, A. (2012). Teori dan Perilaku Organisasi. Malang: UMM Press.
Nevid, J. S., Rathus, S. A., \& Greene, B. (2003). Psikologi Abnormal. Jakarta: Erlangga.

Rini, Jacinta F. (2002). Stress Kerja, (online), Retrivied From: http://www. e-psikologi. com/artikel/organisasiindustri/stress-kerja $\_$(diakses, 22 Mei 2014

Sedarmayanti. (2001). Sumber Daya Manusia dan Produktivitas Kerja. Bandung: Mandar Maju.

Sedarmayanti. (2007). Manajemen SDM Reformasi Birokrasi dan Manajemen PNS. Bandung: PT. Refika Aditama.

Sinungan, M. (2003). Produktivitas Apa dan Bagaimana. Jakarta: Bumi Aksara.

Slamet I. S., Suprapti \& Sumarno M. (2003). Pengantar Psikologi Klinis. Jakarta: Universitas Indonesia Press.

Stoltz, P. G. (2000). Adversity Quotient: Mengubah Hambatan Menjadi Peluang. Jakarta: IKAPI.

Suhariadi, F. (2005). Diskripsi Adversity Quotient dan Perilaku Produktif dari Pemogok Kerja. INSAN Media Psikologi, 7(1), 4569.

Wijono, Sutarto. (2011). Psikologi Industry dan Organisasi. Jakarta: Kencana 
Nazilatur Rochmawati, M. Wardianto

Winarsunu, Tulus. (2011). Psikologi

Keselamatan Kerja. Malang: UMM

Press. 